Cereal Research Communications DOI: $10.1556 / C R C .2013 .0021$

\title{
Response of Wheat Fungal Diseases to Elevated Atmospheric $\mathrm{CO}_{2}$ Level
}

\author{
S. BENCZE*, G. VidA, K. BAlla, E. VARGA-LÁszló and O. VEISZ \\ Cereal Resistance Breeding Department, Agricultural Institute, Centre for Agricultural Research, \\ Hungarian Academy of Sciences, Brunszvik u. 2, H-2462 Martonvásár, Hungary \\ (Received 20 June 2012; accepted 25 October 2012; \\ Communicated by H. Bürstmayr)
}

\begin{abstract}
Infection with fungal pathogens on wheat varieties with different levels of resistance was tested at ambient (NC, $390 \mathrm{ppm}$ ) and elevated (EC, $750 \mathrm{ppm})$ atmospheric $\mathrm{CO}_{2}$ levels in the phytotron. EC was found to affect many aspects of the plant-pathogen interaction. Infection with most fungal diseases was usually found to be promoted by elevated $\mathrm{CO}_{2}$ level in susceptible varieties. Powdery mildew, leaf rust and stem rust produced more severe symptoms on plants of susceptible varieties, while resistant varieties were not infected even at EC. The penetration of Fusarium head blight (FHB) into the spike was delayed by EC in Mv Mambo, while it was unaffected in Mv Regiment and stimulated in Mv Emma. EC increased the propagation of FHB in Mv Mambo and Mv Emma. Enhanced resistance to the spread of Fusarium within the plant was only found in Mv Regiment, which has good resistance to penetration but poor resistance to the spread of FHB at NC. FHB infection was more severe at EC in two varieties, while the plants of Mv Regiment, which has the best field resistance at NC, did not exhibit a higher infection level at EC.

The above results suggest that breeding for new resistant varieties will remain a useful means of preventing more severe infection in a future with higher atmospheric $\mathrm{CO}_{2}$ levels.
\end{abstract}

Keywords: Triticum aestivum, elevated $\mathrm{CO}_{2}$, powdery mildew, leaf rust, stem rust, Fusarium culmorum

\section{Introduction}

The disease resistance of plants is influenced by a variety of environmental factors. Over the last 200 years, the global ecosystem has been exposed to an accelerating rate of change as a consequence of human activity. The rise in the $\mathrm{CO}_{2}$ level is thought to play a major role in global climate change. High atmospheric $\mathrm{CO}_{2}$ levels affect the metabolism, physiology and development of the plant; which, in turn, has an impact on pathogen invasion and disease progress. Although the impact of elevated $\mathrm{CO}_{2}$ level on plants is well-known, much less attention has been paid to the interaction between plants and diseases (Newton et al. 2011; Pangga et al. 2011).

* Corresponding author; E-mail: bencze.szilvia@agrar.mta.hu 
In previous work, the following general tendencies have been reported in response to high $\mathrm{CO}_{2}$ levels (based on reviews by Manning and von Tiedemann 1995; Chakraborty et al. 1998; Coakley et al. 1999; Chakraborty and Datta 2003; Chakraborty et al. 2008):

(i) The change in microclimate resulting from increased leaf mass and biomass may enhance the risk of infection by most microorganisms. An increase in the root mass may affect root pathogens, parasites and symbiotic interactions in the soil. Greater plant biomass may increase the amount of residues in the soil, which could favour necrotrophic organisms and promote the over-wintering of pathogens and pests;

(ii) The greater assimilation of carbon may result in a change in the carbon to nitrogen ratio in plant tissues, and lower $\mathrm{N}$ content may influence the extent of damage caused by certain plant pathogens (McElrone et al. 2005). Higher carbohydrate concentration within the host tissue promotes the development of certain biotrophic pathogens such as rusts (Gassner and Straib 1930), although increased silicon accumulation may inhibit others, such as mildews, due either to the higher proportion of conidia being arrested at the appressorial stage or to the slower development of the fungus (Hibberd et al. 1996a);

(iii) Partial stomatal closure due to high $\mathrm{CO}_{2}$ concentration may hinder the entry of pathogens that germinate through the stomata and enter with the air flow (Royle and Thomas 1971; Ramos and Violin 1987), while lower humidity on the leaf surface may also delay pathogen invasion (Eastburn et al. 2011);

(iv) Infection by powdery mildew accelerated the decline in the net photosynthesis of leaves (Hibberd et al. 1996b). A faster rate of phenological development and earlier maturation might favour necrotrophic over biotrophic organisms.

Earlier research revealed increased pathogen fecundity in plant species other than cereals in the case of bacterial, viral and fungal diseases (e.g. Chakraborty and Datta 2003), but this idea is not always supported by the latest findings (Eastburn et al. 2011, Pangga et al. 2011). Disease severity is determined on the one hand by enhanced host resistance, which slows pathogen penetration and on the other by an enlarged plant canopy, which offers more infection sites and affects the microclimate. In the long run, higher pathogen fecundity, inoculum trapping by an enlarged plant canopy, and a higher number of infection cycles all interact with the effects of enhanced host resistance to determine host-pathogen adaptation (Chakraborty et al. 2008).

An increase in protective compounds at elevated $\mathrm{CO}_{2}$ level may reduce infection success (McElrone 2005), although reduced or unchanged protection was also reported in response to $\mathrm{CO}_{2}$ enrichment (Eastburn et al. 2011). The trichome density of Brassica rapa leaves increased by $57 \%$ under elevated $\mathrm{CO}_{2}$ and the level of phenolics was also higher (Karowe and Grubb 2011). In addition, constitutive phenolic levels were positively correlated with the leaf $\mathrm{C}: \mathrm{N}$ ratio. Investigations on powdery mildew in wheat proved that the host nitrogen content was lower at elevated $\mathrm{CO}_{2}$, resulting in a lower rate of infection; however, when the tissue water content was higher, the disease was more severe 
(Thomson et al. 1993). The aggressiveness of Erysiphe cichoracearum in Arabidopsis was, however, found to increase at elevated $\mathrm{CO}_{2}$, as the pathogen induced morphological changes in later-formed leaves of the host plants, thus promoting the propagation of the disease (Lake and Wade 2009).

Increased plant growth rate may increase the progression of the pathogen in the canopy (Eastburn et al. 2011), thus affecting epidemiological and evolutionary perspectives (Pangga et al. 2011). This raises important questions regarding the sustainability of agricultural production and future challenges for breeding (Gregory et al. 2009).

Although several plant species and pathogens have been investigated in previous research, there is still a lack of information on the performance of most cereal diseases in response to high $\mathrm{CO}_{2}$ concentration. The aim of the present work was to test the impact of atmospheric $\mathrm{CO}_{2}$ enrichment on the resistance of winter wheat varieties to fungal pathogens in terms of the emergence of the symptoms and disease progress. Wheat varieties with different levels of disease resistance were chosen for tests on the variation in their responses.

\section{Materials and Methods}

Vernalized seedlings of three Hungarian winter wheat varieties (Mv Regiment, Mv Emma, and Mv Mambo) were planted in pots (four plants in each 3L pot, eight pots per variety and per disease treatment) and grown in PGV-36 growth chambers either at ambient $(\mathrm{NC}, 390 \mathrm{ppm})$ or elevated (EC, $750 \mathrm{ppm}) \mathrm{CO}_{2}$ levels. The plants were watered daily and supplied with nutrients in tap-water ( $3 \mathrm{dL} /$ pot) twice a week, in the form of $0.33 \mathrm{~g} / 1$ nutrient solution (Volldünger Linz Classic, Gartenhilfe GmbH., Austria) containing $3.3 \mathrm{mM}$ $\mathrm{N}, 0.163 \mathrm{mM} \mathrm{P}, 0.736 \mathrm{mM} \mathrm{K}, 0.082 \mathrm{mM} \mathrm{Mg}$ and $0.033 \%$ microelements (B, Cu, Mn, Fe, $\mathrm{Zn}$ ). The temperature regime changed weekly according to the T2-Ny2 (Spring 2-Summer 2) climatic programme (Tischner et al. 1997) beginning with a $\mathrm{min} / \mathrm{max}$ of $10 / 12^{\circ} \mathrm{C}$ during the first week and increasing until it reached $16 / 20^{\circ} \mathrm{C}$, before the period of infection. The maximum photosynthetic photon flux density also increased gradually from 280 to 350 $\mu \mathrm{mol} \mathrm{m} \mathrm{m}^{-2} \mathrm{~s}^{-1}$ (Tischner et al. 1997). To prevent powdery mildew infection, chemical control with elemental sulphur was applied three times during the period preceding the treatments. In the other group of plants, where no sulphur treatment was applied, the disease symptoms of spontaneously occurring powdery mildew (Blumeria graminis, PM) infection were evaluated using a 0-9 scale (Saari and Prescott 1975 cit. Stubbs et al. 1986) around weeks four and six after planting.

To test resistance to leaf rust (LR, Puccinia triticina), stem rust (SR, Puccinia graminis) and Fusarium head blight (FHB, Fusarium culmorum) the plants were artificially inoculated as follows:

For the rust pathogens, the washed and wiped, still damp surfaces of a single fully expanded flag-leaf on each plant were inoculated with uredospores suspended in tap water (2.7 million $\mathrm{mL}^{-1}$ for $\mathrm{LR}, 0.9$ million $\mathrm{mL}^{-1}$ for SR) using a brush. For FHB, two kinds of tests were performed either to examine resistance to fungal spread from an inoculated spikelet (Type II resistance, Schroeder and Christensen, 1963) or to test combined resistance to penetration and spread of the pathogen (Type I+II resistance, Schroeder and 
Christensen, 1963). In the case of single floret inoculation, one spikelet (usually the $6^{\text {th }}-8^{\text {th }}$ from the top of each spike, but the $10^{\text {th }}$ in Mv Emma) was injected with a pipette at anthesis with $5 \mathrm{ml}$ inoculum $\left(500,000\right.$ conidia $\left.\mathrm{mL}^{-1}\right)$, while in the latter type of infection a suspension of F. culmorum spores ( 50.000 conidia $\mathrm{mL}^{-1}$ ) was spread along the entire surface of each spike using a brush. In all cases of artificial infection with either disease, the inoculated plant parts were covered with a plastic bag for 72 hours to provoke successful establishment of the pathogen.

The disease progress of LR, SR and FHB was monitored till the start of maturation and the area under the disease progress curve (AUDPC) was calculated accordingly (Campbell et al. 1990). The results were evaluated with the Mann-Whitney Test (SPSS 16.0).

\section{Results}

\section{Powdery mildew}

Powdery mildew appeared spontaneously on the susceptible varieties (Mv Mambo and Mv Emma) both of which had significantly higher levels of infection at both evaluation dates as a result of elevated $\mathrm{CO}_{2}$ level (Table 1). In the resistant variety $\mathrm{Mv}$ Regiment, however, there were no infected plants even at the high $\mathrm{CO}_{2}$ level.

Table 1. Effect of $\mathrm{CO}_{2}$ level (normal, $\mathrm{NC}$, elevated, $\mathrm{EC}$ ) on powdery mildew severity in susceptible wheat varieties.

\begin{tabular}{lccc}
\hline Powdery mildew & Infected & \multicolumn{2}{c}{ Mean scale value } \\
\cline { 2 - 4 } & plants/total & Evaluation 1 & Evaluation 2 \\
\hline Mv Emma NC & $17 / 32$ & 0.41 & 0.73 \\
Mv Emma EC & $29 / 32$ & 3.11 & 3.00 \\
Asymp. Sig. (2-tailed)* & 0.000 & 0.000 & 2.03 \\
\hline Mv Mambo NC & $31 / 32$ & 0.92 & 2.70 \\
Mv Mambo EC & $32 / 32$ & 2.48 & \\
Asymp. Sig. (2-tailed)* & 0.000 & 0.003 & \\
\hline
\end{tabular}

* Mann-Whitney Test

\section{Leaf rust}

Elevated $\mathrm{CO}_{2}$ concentration resulted in greatly enhanced severity of leaf rust in Mv Regiment (Table 2). Although both Mv Regiment and Mv Emma were found to be susceptible to LR in artificially inoculated field nursery tests (with $100 \%$ and $80 \%$ infection of the foliage, respectively, based on the modified Cobb's scale; Peterson et al. 1948), under the present conditions $\mathrm{Mv}$ Emma was not infected at ambient $\mathrm{CO}_{2}$ and was only slightly infected at high $\mathrm{CO}_{2}$. The difference was, however, significant. In the resistant variety, $\mathrm{Mv}$ Mambo, there was no change due to high $\mathrm{CO}_{2}$, as no infection was detected at either level. 
Table 2. Effect of $\mathrm{CO}_{2}$ level (normal, $\mathrm{NC}$, elevated, $\mathrm{EC}$ ) on leaf rust severity in susceptible wheat varieties

\begin{tabular}{lccccc}
\hline \multirow{2}{*}{ Leaf rust } & \multicolumn{2}{c}{ Infected } & \multicolumn{4}{c}{ Mean number of pustules leaf $^{-1}$} \\
\cline { 2 - 6 } & plants/total & Day 7 & Day 14 & Day 21 & AUDPC** $^{*}$ \\
\hline Mv Regiment NC & $31 / 32$ & 0.03 & 1.66 & 15.69 & 69.0 \\
Mv Regiment EC & $32 / 32$ & 0.65 & 9.65 & 35.96 & 197.9 \\
Asymp. Sig. (2-tailed)* & 0.004 & 0.000 & 0.000 & 0.000 & \\
\hline Mv Emma NC & $0 / 32$ & 0 & 0 & 0 & - \\
Mv Emma EC $_{\text {Asymp. Sig. (2-tailed)* }}$ & $9 / 32$ & 1.0 & 3.5 & 6.7 & - \\
\hline
\end{tabular}

* Mann-Whitney Test

**Calculated from data for days 0 (equivalent to 0 ) to 21 after inoculation.

\section{Stem rust}

Stem rust severity in the susceptible variety (Mv Emma, 80\% in artificially inoculated field nursery tests) was also higher at elevated $\mathrm{CO}_{2}$ (Table 3), but did not change significantly in the more resistant genotype (Mv Regiment, 10\% infection). In Mv Mambo, which is resistant to SR, no disease symptoms were observed at either $\mathrm{CO}_{2}$ level.

Table 3. Effect of $\mathrm{CO} 2$ level (normal, NC, elevated, EC) on stem rust severity in susceptible wheat varieties

\begin{tabular}{lcccr}
\hline \multirow{2}{*}{ Stem rust } & \multicolumn{3}{c}{ Infected } & \multicolumn{2}{c}{ Mean number of pustules leaf } \\
\cline { 2 - 5 } & plants/total & Day 7 & Day 14 & AUDPC** $^{-1}$ \\
\hline Mv Regiment NC & $20 / 32$ & 0.88 & 2.19 & 13.8 \\
Mv Regiment EC & $16 / 31$ & 0.29 & 1.87 & 8.6 \\
Asymp. Sig. (2-tailed)* & 0.063 & 0.423 & 0.295 & 52.3 \\
\hline Mv Emma NC & $9 / 16$ & 4.31 & 6.31 & 1132.7 \\
Mv Emma EC & $13 / 16$ & 92.81 & 138.00 & 0.010 \\
Asymp. Sig. (2-tailed)* & 0.013 & 0.009 & & \\
\hline
\end{tabular}

* Mann-Whitney Test

**Calculated from data for days 0 (equivalent to 0 ) to 14 after inoculation.

\section{Resistance to the spread of FHB along the spike}

Mv Regiment was the most susceptible variety to the spread of Fusarium at ambient $\mathrm{CO}_{2}$ (Fig. 1), while at elevated $\mathrm{CO}_{2}$, FHB spread was significantly reduced from day 18 onwards following inoculation $(\mathrm{p}=0.002)$, compared to the rate at ambient $\mathrm{CO}_{2}$. There was no significant change in FHB severity in $\mathrm{Mv}$ Mambo in response to elevated $\mathrm{CO}_{2}$. In $\mathrm{Mv}$ Emma, however, the establishment of Fusarium was significantly delayed at high $\mathrm{CO}_{2}$ level ( $p=0.024$ and 0.060 on days 7 and 11 , respectively), but later no difference could be seen in the number of infected spikelets, and the disease became even more severe at high $\mathrm{CO}_{2}$ than at 


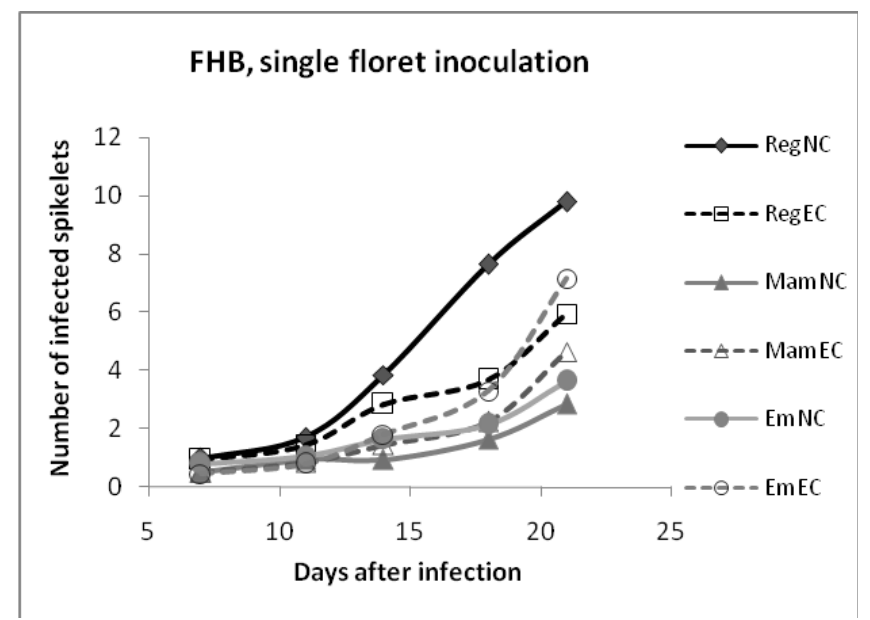

Figure 1. Fusarium head blight infection on the spikes of winter wheat varieties at normal (NC) and elevated (EC) $\mathrm{CO}_{2}$ levels. Single floret inoculation. $\mathrm{Reg}=\mathrm{Mv}$ Regiment, $\mathrm{Mam}=\mathrm{Mv}$ Mambo, Em $=$ Mv Emma

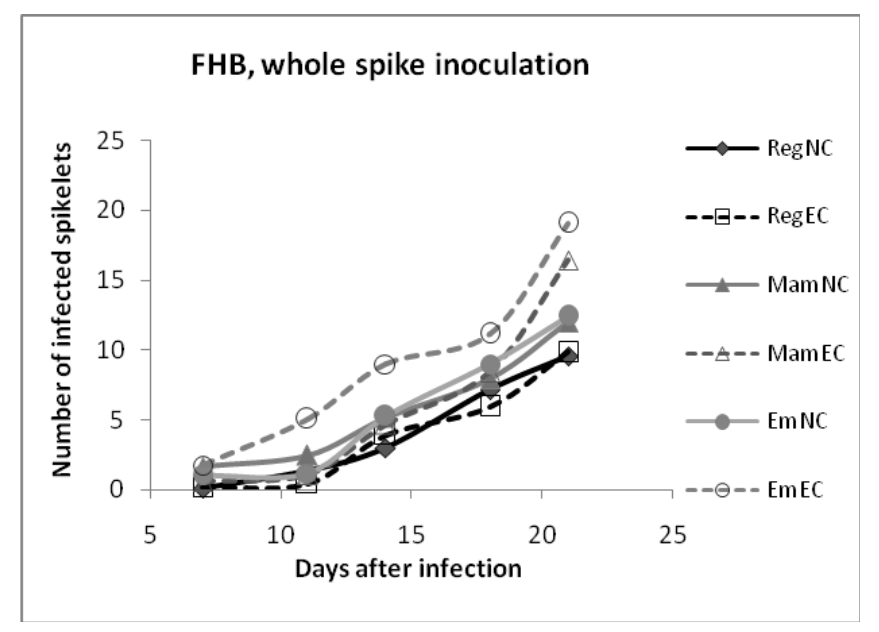

Figure 2. Fusarium head blight infection on the spikes of winter wheat varieties at normal (NC) and elevated (EC) $\mathrm{CO} 2$ levels. Whole spike inoculation. (For abbreviations see Fig. 1)

\section{Combined resistance to the penetration and spread of FHB}

Fusarium inoculation of the whole spike revealed variety- and phase-specific reactions (Fig. 2). Usually several spikelets in a spike became infected at the same time. The penetration of Fusarium was delayed in Mv Mambo at elevated $\mathrm{CO}_{2} ; \mathrm{FHB}$ severity was still lower on days 7 and 11 than at the ambient level ( $p=0.043$ and 0.015 , respectively). After successful establishment, however, the pathogen spread faster through the rachis, result- 
ing in a higher infection rate at high $\mathrm{CO}_{2}$ by the third week $(\mathrm{p}=0.053)$. In $\mathrm{Mv}$ Emma, Fusarium infection was more severe at elevated $\mathrm{CO}_{2}$ on all sampling dates (significantly on days 11 and 21). $\mathrm{CO}_{2}$ enrichment had no influence on FHB severity in Mv Regiment at any time. This variety exhibited the lowest rate of infection when whole spike surfaces were inoculated while it was highly susceptible to fungal spread in the case of single floret inoculation.

\section{Discussion}

In the susceptible varieties, powdery mildew caused a considerably higher rate of infection in response to $\mathrm{CO}_{2}$ enrichment, in accordance with the work of Lake and Wade (2009), who reported 40\% more established colonies of another mildew species, Erysiphe cichoracearum, in Arabidopsis due to EC. Hibberd et al. (1996a) found partly similar results; if PM was successful in forming colonies on barley leaves, it spread rapidly due to the greater accumulation of carbohydrates in the host plant at high $\mathrm{CO}_{2}$ level. It was observed, however, that although the number of conidia germinating on the leaf surface was the same at normal and doubled $\mathrm{CO}_{2}$ level, there was a substantial decline in the number of conidia capable of forming colonies at high $\mathrm{CO}_{2}$ level. The inhibition of the pathogen could be attributed to the intensified photosynthesis, which resulted in the accumulation of protective compounds and structures (e.g. papillae, silicon) at the site of pathogen invasion. An apparently contrasting result was also found in wheat; high $\mathrm{CO}_{2}$ level resulted in significantly reduced tissue $\mathrm{N}$ contents, which caused less severe infection with PM (Thompson et al. 1993). This apparent contradiction could be due to the fact that in the latter experiment either the conidia were incapable of forming colonies at high $\mathrm{CO}_{2}$ (as was described by Hibberd et al. 1996a) or/and the tissue nitrogen content dropped so much that it was far below the optimum required to support the spread of the fungus. McElrone (2005) also reported reduced the nutritive quality and increased amount of protective compounds in Acer leaves at EC as a possible cause for reduced disease severity. The above findings suggest that a higher level of infection can only be expected at $\mathrm{EC}$ when the plants have a better nutrient supply, capable of counteracting, at least to some extent, the dilution of the plant nutrient content caused by EC.

As the plants in the present study became infected spontaneously during a very early stage of development, before they were fully adapted to the elevated $\mathrm{CO}_{2}$ level, there may have been little difference in the extent of penetration in plants at the ambient and high $\mathrm{CO}_{2}$ levels. This hypothesis will require further investigation. It was proved, however, that the resistant variety was unaffected by high $\mathrm{CO}_{2}$, as no PM infection was detected even at EC. These findings contradict those reported for Arabidopsis by Lake and Wade (2009), who suggested that resistant ecotypes may become more susceptible to infection under EC.

The present experiment also revealed increased fecundity for leaf rust and stem rust, though there were certain differences between the two susceptible wheat varieties. A higher density of leaf rust pustules was observed on the leaves of the very susceptible variety at high $\mathrm{CO}_{2}$, while the less susceptible variety was not infected at ambient $\mathrm{CO}_{2}$ but be- 
came slightly infected at elevated $\mathrm{CO}_{2}$ level. Stem rust was considerably more severe in the susceptible variety in response to $\mathrm{CO}_{2}$ enrichment, but there was no significant change in the more tolerant variety. In both rust species, the resistant variety remained resistant even at high $\mathrm{CO}_{2}$ concentration. This suggests that breeding for new resistant varieties will remain a useful means to prevent more severe infection in a future with higher atmospheric $\mathrm{CO}_{2}$ levels.

As little information has been published so far on the effect of elevated $\mathrm{CO}_{2}$ level on rust species it is difficult to make a relevant comparison. In early works, high $\mathrm{CO}_{2}$ concentration was only applied after inoculation, so these results may have limited general applicability, despite the fact that enhanced infection rates were found for various cereal species (Gassner and Straib 1930; Volk 1931). Later works reported results different from the present findings; e.g. EC was found to have no effect on rust infection in tree species (Eastburn et al. 2011). The incidence of other diseases in trees was also reduced at EC, e.g. Phyllosticta minima in Acer (McElrone et al. 2005), nor was any change reported in the uredospore production per unit lesion area or in the disease progress of Puccinia striiformis (stripe rust) in FACE experiments (preliminary results, Chakraborty et al. 2010).

In the present work the penetration phase of infection and the latent period were not investigated, so no data are available on whether there was any difference in these factors due to $\mathrm{CO}_{2}$ enrichment. For Fusarium head blight, however, the penetration of the fungus and the progress in the rachis was studied separately by applying specific inoculation methods.

In the case of Mv Mambo, the penetration of Fusarium was delayed at high $\mathrm{CO}_{2}$, but following establishment, the spread of the disease was even faster than at NC. This was very similar to the situation with PM in barley, described by Hibberd et al. (1996a). This suggests that the pathogen adapts to the circumstances in plants grown at elevated $\mathrm{CO}_{2}$. Another feature suggesting some kind of adaptation to the host conditions was that aggressiveness increased (the spread of FHB was accelerated) by the third week after inoculation, irrespective of the $\mathrm{CO}_{2}$ level. In the most susceptible variety, Mv Emma, no delay was observed and FHB was more severe at elevated $\mathrm{CO}_{2}$ at all the dates. In $\mathrm{Mv}$ Regiment, which was the least susceptible variety, a similar rate of infection was observed at both ambient and elevated $\mathrm{CO}_{2}$ levels. The variation found here between wheat varieties was in accordance with previous results reported by Melloy et al. (2010) on Fusarium pseudograminearum, which causes wheat crown rot. These authors found increased fungal biomass and/or increased stem browning in response to EC in some situations, which exhibited variety dependence.

When the inoculum was injected directly into the spikelet to test the spread of Fusarium (single floret inoculation), no difference was observed between plants grown at different $\mathrm{CO}_{2}$ levels in Mv Mambo, while in Mv Emma, despite the initial delay in the appearance of the disease symptoms, the disease became more severe at EC. Increased resistance was detected, however, in the third variety (Mv Regiment), which had the poorest resistance to fungal spread at ambient $\mathrm{CO}_{2}$. This may have been due to structural changes or protective compounds, and needs further investigation. 
Other research done on maize suggested that Fusarium ear infection might be reduced at $550 \mathrm{ppm} \mathrm{CO}$, as the DON (deoxynivalenol) concentrations detected in maize kernels in one year of the experiment (2007) were significantly reduced compared to those recorded at $380 \mathrm{ppm} \mathrm{CO} \mathrm{CO}_{2}$ (Oldenburg et al. 2009). However, the infection was very low, so no visible differences in the symptoms could be detected between the $\mathrm{CO}_{2}$ levels. These results contradict those found in the present work on wheat. Although elevated $\mathrm{CO}_{2}$ level delayed the establishment of FHB in some cases, after a time the disease generally became more severe at high $\mathrm{CO}_{2}$. In one variety, $\mathrm{Mv}$ Regiment, however, no visible difference in Fusarium infection was detected, as in the work of Oldenburg et al. (2009). The present results underline the importance of differences between varieties, originating from either their different genetic backgrounds, and/or the type of resistance or the level of susceptibility.

The present study provided practical answers to the question of how elevated atmospheric $\mathrm{CO}_{2}$ level affects the onset and severity of several fungal diseases in wheat (For summary see Table 4). The process of pathogen invasion was studied for Fusarium culmorum. The results showed that elevated $\mathrm{CO}_{2}$ level caused a delay (Mv Mambo), had no effect (Mv Regiment) or promoted (Mv Emma) the penetration of Fusarium. This was in accordance with previous work, where the penetration of pathogens and/or the process of the infection was found to be delayed in some but not all cases (Coakley et al. 1999, McElrone et al. 2005, Eastburn et al. 2011). In both biotrophic and necrotrophic organisms, significant changes were reported in the onset and duration of the stages in the pathogen life cycle under elevated $\mathrm{CO}_{2}$. The latent period, the time between inoculation and sporulation, was sometimes longer at high $\mathrm{CO}_{2}$ (Chakraborty et al. 1998). The present resistance tests performed by direct inoculation of single florets also pointed to a longer latent period in one variety, Mv Emma, before Fusarium symptoms became visible.

Table 4. Summary of changes in wheat diseases in response to elevated $\mathrm{CO}_{2}$

\begin{tabular}{|c|c|c|c|c|c|c|c|}
\hline & $\begin{array}{l}\text { Powdery } \\
\text { mildew }\end{array}$ & $\begin{array}{l}\text { Leaf } \\
\text { rust }\end{array}$ & $\begin{array}{l}\text { Stem } \\
\text { rust }\end{array}$ & $\begin{array}{c}\text { Penetration } \\
\text { of } \\
\text { Fusarium }\end{array}$ & $\begin{array}{l}\text { Rate of } \\
\text { spread of } \\
\text { Fusarium }\end{array}$ & $\begin{array}{c}\text { Severity of } \\
\text { Fusarium } \\
\text { infection } \\
\text { WSI }\end{array}$ & $\begin{array}{l}\text { Severity of } \\
\text { Fusarium } \\
\text { infection } \\
\text { SFI }\end{array}$ \\
\hline \multicolumn{8}{|l|}{ Ambient $\mathrm{CO}_{2}$} \\
\hline Mv Mambo & + & 0 & 0 & ++ & + & ++ & + \\
\hline Mv Emma & + & 0 & + & ++ & + & ++ & + \\
\hline Mv Regiment & 0 & + & + & + & +++ & + & +++ \\
\hline \multicolumn{8}{|l|}{ Elevated $\mathrm{CO}_{2}$} \\
\hline Mv Mambo & $++*$ & 0 & 0 & $+*$ & $++*$ & $+++*$ & + \\
\hline Mv Emma & $++*$ & $+*$ & $++*$ & $+++*$ & $++*$ & $+++*$ & $++*$ \\
\hline Mv Regiment & 0 & $++^{*}$ & + & + & $++*$ & + & $++*$ \\
\hline
\end{tabular}

WSI $=$ whole spike inoculation

$\mathrm{SFI}=$ single floret inoculation

$0=$ no symptoms visible

,,$++++++=$ degree of relative severity of disease symptoms

* = significant difference between $\mathrm{CO}_{2}$ levels 
Evidence was also given here that the disease severity and/or reproductive success of most wheat fungal species increased at EC; powdery mildew, leaf rust and stem rust were significantly more severe on the leaves of plants in the susceptible varieties. High $\mathrm{CO}_{2}$ level also increased the propagation of Fusarium in two varieties (Mv Mambo and Mv Emma, whole spike inoculation). Only Mv Regiment had increased resistance to the spread of the fungus at EC. This variety, which had the lowest infection rate at both $\mathrm{CO}_{2}$ levels, proved to be the most resistant of all the varieties, when the pathogen had to invade the plant tissues itself.

Although the diseases were usually more severe in susceptible varieties at elevated $\mathrm{CO}_{2}$, resistant varieties remained resistant even under these conditions. These findings provide important evidence that resistance traits will still be useful in the future when developing new resistant varieties adapted to higher atmospheric $\mathrm{CO}_{2}$ conditions. However, further research will be needed to achieve a better understanding of the processes taking place during penetration and in the early phase of infection.

\section{Acknowledgements}

This research was supported by the projects TÁMOP-4.2.2.b-10/1-2010-0025 and TÁMOP-4.2.2.A-11/1KONV-2012-0064 and the grant OTKA K-105949 from the National Scientific Research Fund.

\section{References}

Campbell, C.L., Madden, L.V. 1990. Introduction to Plant Disease Epidemiology. John Wiley \& Sons, New York, USA, pp. 532.

Chakraborty, S., Murray, G.M., Magarey, P.A., Yonow, T., O’Brien, R.G., Croft, B.J., Barbetti, M.J., Sivasithamparam, K., Old, K.M., Dudzinski, M.J., Sutherst, R.W., Penrose, L.J., Archer, C., Emmett, R.W. 1998. Potential impact of climate change on plant diseases of economic significance to Australia. Australasian Plant Pathology 27:15-35.

Chakraborty, S., Datta, S. 2003. How will plant pathogens adapt to host plant resistance at elevated $\mathrm{CO}_{2}$ under a changing climate? New Phytology 159:733-742.

Chakraborty, S., Luck, J., Hollaway, G., Freeman, A., Norton, R., Garrett, K.A., Percy, K., Hopkins, A., Davis, C., Karnosky, D.F. 2008. Impacts of global change on diseases of agricultural crops and forest trees. CAB Reviews: Perspectives in Agriculture, Veterinary Science, Nutrition and Natural Resources 3:1-15.

Chakraborty, S., Luck, J., Hollaway, G., Fitzgerald, G., White, N. 2010. Rust-proofing wheat for changing climate. BGRI Workshop, May 30-31 2010. Saint Petersburg, Russia. url: http://www.globalrust.org/db/attachments/about/19/15/09-chakraborty\%20BGRI\%20talk.pdf

Coakley, S.M., Scherm, H., Chakraborty, S. 1999. Climate change and plant disease Management. Annu. Rev. Phytopathol. 37:399-426.

Eastburn, D.M., McElrone, A.J., Bilgin, D.D. 2011. Influence of atmospheric and climatic change on plant-pathogen interactions. Plant Pathol. 60:54-69.

Gassner, G., Straib, W. 1930. Untersuchungen über die Abhangigkeit des Infektionsverhaltens der Getreiderostpilze vom Kohlensauregehalt der Luft (Investigations on the dependence of the delay of cereal rust infection on the $\mathrm{CO}_{2}$ content of the air). J. Phytopathol. 1:1-30. (in German)

Gregory, P.J., Johnson, S.N., Newton, A.C., Ingram, J.S.I. 2009. Integrating pests and pathogens into the climate change/food security debate. J. Exp. Bot. 60:2827-2838.

Hibberd, J.M., Whitbread, R., Farrar, J.F. 1996a. Effect of elevated concentrations of $\mathrm{CO}_{2}$ on infection of barley by Erysiphe graminis. Physiol. of Mol. Plant Pathol. 48:37-53.

Cereal Research Communications 
Hibberd, J.M., Whitbread, R., Farrar, J.F. 1996b. Effect of $700 \mu \mathrm{mol}$ per $\mathrm{mol} \mathrm{CO}_{2}$ and infection of powdery mildew on the growth and partitioning of barley. New Phytologist 134:309-345.

Karowe, D.N., Grubb, C. 2011. Elevated $\mathrm{CO}_{2}$ increases constitutive phenolics and trichomes, but decreases inducibility of phenolics in Brassica rapa (Brassicaceae) J. Chemical Ecol. 37:1332-1340.

Lake, J.A., Wade, R.N. 2009. Plant-pathogen interactions and elevated $\mathrm{CO}_{2}$ : Morphological changes in favour of pathogens. J. Exp. Bot. 60:3123-3131.

Manning, W.J., von Tiedemann, A. 1995. Climate change: Potential effects of increased atmospheric carbon dioxide $\left(\mathrm{CO}_{2}\right)$, ozone $\left(\mathrm{O}_{3}\right)$, and ultraviolet-B (UV-B) radiation on plant diseases. Environmental Pollution 8:219-245.

McElrone, A.J., Reid, C.D., Hoye, K.A., Hart, E., Jackson, R.B. 2005. Elevated $\mathrm{CO}_{2}$ reduces disease incidence and severity of a red maple fungal pathogen via changes in host physiology and leaf chemistry. Global Change Biology 11:1828-1836.

Melloy, P., Hollaway, G., Luck, J., Norton, R., Aitken, E., Chakraborty, S. 2010. Production and fitness of Fusarium pseudograminearum inoculum at elevated carbon dioxide in FACE. Global Change Biology 16:3363-3373.

Newton, A.C., Johnson, S.N., Gregory, P.J. 2011. Implications of climate change for diseases, crop yields and food security. Euphytica 179:3-18.

Oldenburg, E., Manderscheid, R., Erbs, M., Weigel, H.J. 2009. Interaction of free air carbon dioxide enrichment (FACE) and controlled summer drought on fungal infections of maize. In: Feldmann, F., Alford, D.V., Furk, C. (eds), Crop Plant Resistance to Biotic and Abiotic Factors. Deutsche Phytomedizinische Gesellschaft, Braunschweig, Germany, pp. 75-83.

Pangga, I.B., Hannan, J., Chakraborty, S. 2011. Pathogen dynamics in a crop canopy and their evolution under changing climate. Plant Pathol. 60:70-81.

Peterson, R.F., Campbell, A.B., Hannah, A.E. 1948. A diagrammatic scale for estimating rust intensity of leaves and stem of cereals. Canadian J. of Research 26:496-500.

Ramos, L.J., Violin, R.B. 1987. Role of stomatal opening and frequency on infection of Lycopersicon spp. by Xanthomonas campestris pv. versicatoria. Phytopatology 77:1311-1317.

Royle, D.J., Thomas, G.G. 1971. The influence of stomatal opening on the infection of hop leaves by Pseudoperonospora humuli. Observations with the scanning electron microscope on the early stages of hop leaf infection by Pseudoperonospora humuli. Physiology of Plant Pathol. 33:329-343.

Saari, E.E., Prescott, J.M. 1975. A scale for appraising the foliar intensity of wheat disease. Plant Disease Reporter 59:377-380.

Schroeder, H.W., Christensen, J.J. 1963. Factors affecting resistance of wheat to scab caused by Gibberella zeae. Phytopathol. 53:831-838

Stubbs, R.W., Prescott, J.M., Saari, E.E., Dubin, H.J. 1986. Cereal Disease Methodology Manual. Centro Internacional de Mejoramiento de Maízey Trigo (CIMMYT), Mexico, p. 46.

Thompson, G.B., Brown, J.K.M., Woodward, F.I. 1993. The effects of host carbon dioxide, nitrogen and water supply on the infection of wheat by powdery mildew and aphids. Plant, Cell \& Environment 16:687-694.

Tischner, T., Kőszegi, B., Veisz, O. 1997. Climatic programmes used in the Martonvásár Phytotron most frequently in recent years. Acta Agronomica Hungarica 45:85-104.

Volk, A. 1931. Einflüsse des Bodens, der Luft und des Lichtes auf die Empfänglichkeit der Pflanzen für Krankheiten (Effect of soil, air and light on the susceptibility of plants to diseases). J. of Phytopathol. 3:1-88. (in German) 